Article

\title{
Long-Term Influence of Stump-Removal on Components of Hemiboreal Pine Forest Ecosystem
}

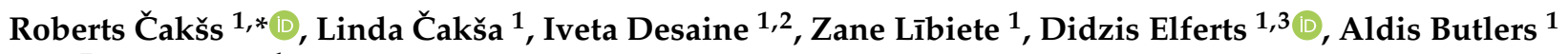 \\ and Āris Jansons ${ }^{1}$ \\ 1 Latvian State Forest Research Institute "SILAVA", LV-2169 Salaspils, Latvia; linda.caksa@gmail.com (L.Č.); \\ iveta.desaine@skogssallskapet.com (I.D.); zane.libiete@silava.lv (Z.L.); didzis.elferts@lu.lv (D.E.); \\ aldis.butlers@silava.lv (A.B.); aris.jansons@silava.lv (Ā.J.) \\ 2 "Skogssallskapet" SIA, LV-4101 Cēsis, Latvia \\ 3 Faculty of Biology, University of Latvia, LV-1004 Riga, Latvia \\ * Correspondence: roberts.cakss@silava.lv; Tel.: +371-286-67-463
}

Citation: Čakšs, R.; Čakša, L.; Desaine, I.; Lībiete, Z.; Elferts, D.; Butlers, A.; Jansons, Ā. Long-Term Influence of Stump-Removal on Components of Hemiboreal Pine Forest Ecosystem. Sustainability 2021, 13, 2095. https://doi.org/10.3390/ su13042095

Academic Editor: Sara Burbi

Received: 22 December 2020

Accepted: 10 February 2021

Published: 16 February 2021

Publisher's Note: MDPI stays neutral with regard to jurisdictional claims in published maps and institutional affiliations.

Copyright: (c) 2021 by the authors. Licensee MDPI, Basel, Switzerland. This article is an open access article distributed under the terms and conditions of the Creative Commons Attribution (CC BY) license (https:// creativecommons.org/licenses/by/ $4.0 /)$.

\begin{abstract}
Use of whole tree biomass becomes increasingly more important due to rising demand for renewable energy and materials to replace fossil resources. Therefore, assessment of influence of this approach on hemiboreal forest ecosystem is essential. The aim of our study was to assess the long-term influence of full biomass removal (FBR) on the ground vegetation and soil chemical composition in Scots pine stands. Study sites were located in Vacciniosa, Myrtillosa, and Myrtillosa mel. forest types. Almost half a century from the FBR, it had no notable or significant influence on number of ground vegetation species. Significant differences in overall vegetation composition between stands established after FBR and conventional harvesting (stem-wood removal) were not found by the detrended correspondence analysis (DCA) and analysis of similarities (ANOSIM). In addition, values of Ellenberg and Düll indicators were similar and, in most cases (determined by forest type and parameter), had no significant differences between FBR and the same age control stands. Similarly, no significant differences were found between these stands in soil carbon and nitrogen pools. Thus, there had not been a negative long-term effect of FBR on the hemiboreal Scots pine ecosystem as indicated by ground vegetation and soil.
\end{abstract}

Keywords: full biomass gathering; vegetation; long-term effects; soil chemical composition; detrended correspondence analysis

\section{Introduction}

The aim of stump harvesting has been, and still is, to ensure additional wood resources. Historically, stumps have been a resource for tar [1,2] or chemical processing [3]; currently, they are viewed as a source for bioenergy. Whole tree harvesting instead of conventional harvesting (stem wood use from clear-cuts) will increase the usable wood production by $30 \%$, depending on trees species and conditions $[4,5]$. For Scots pine (Pinus sylvestris L.), harvestable amount of stumps and coarse roots is about $11 \%$ to $18 \%$, and biomass from stem and branches is about from $78 \%$ to $83 \%$, and the fine roots and needles are approximately 6\% [4,6-8]. For Norway spruce (Picea abies), the amount of harvestable stem and branch biomass is from $60 \%$ to $72 \%$, the stump and coarse roots are from $18 \%$ to $21 \%$ of all tree biomass, and needles, cones, and small and fine roots are approximately $22 \%[5,6]$. In Northern Europe, stump harvesting is primarily practiced in Norway spruce forests of Finland. The amount that Finland harvests from stumps and roots is on average 0.76 million $\mathrm{m}^{3}$ per year, with notable variation between years. It reached a peak from 2010 to 2013 [9]. Factors driving the stump harvesting are the technologies and costs (dependent on the technologies and amount of obtainable material), as well as considerations on the potential influence of this practice to the forest ecosystem. 
Stumps can be removed (bulldozed) with the upper layer of soil [10]; however, it creates difficulties to obtain clean wood for further processing. Therefore, in current practice, stumps are lifted with as little soil attached as possible [11,12]. After stump harvesting, the pits are closed by adjacent soil [13]. Studies have shown that stump harvesting mixes soil layers [13], causing faster decomposition of vegetation and litter and loss (leakage) of nutrients and slower vegetation regeneration [14]. In addition, additional activities while removing and collecting the stumps increase the soil compaction This damage can be partly reduced by training operators and using adjusted machinery with lower pressure to forest floor $[13,15]$. Some nutrients were removed from the forest area with the harvested stumps and roots themselves and/or upper $(0-20 \mathrm{~cm})$ soil layer, like $\mathrm{Ca}^{2+}, \mathrm{K}^{+}, \mathrm{Mg}^{2+}, \mathrm{Na}^{+}, \mathrm{Mn}^{2+}$, $\mathrm{N}, \mathrm{C}, \mathrm{P}[16,17]$. Stumps have a notable role in carbon and nitrogen circulation: after harvesting, carbon is very gradually released to the atmosphere. Nitrogen accumulates when the stumps decompose $[18,19]$. By removing all tree biomass from a forest stand, nutrient loss is significantly higher, in comparison to only stump harvesting, since needles/leaves and twigs have the highest nutrient amount and concentration [20,21]. Nutrient removal might affect the growth of next tree generation at early stages [8]. However, it does not necessarily lead to reduced increment over a longer period, as has been seen for Scots pine on fertile soil [22].

Forest management affects soil invertebrates, earthworms, and nematodes: their number is most dramatically reduced after clear-cut, and especially after stump harvesting, because of microclimate change and removal of organic material from the forest floor [12,23]. Similarly, such drastic changes influence ground vegetation; the microclimate changes, new, light-demanding species rapidly spread, but shade tolerance plants species perish [24] Stump harvesting creates five times more ground disturbance than conventional clearcutting [25]. In such conditions, ingrowth of new vascular plant species is more rapid, since they do not have to compete with much of existing (pre-harvest) vegetation [26]. The stump harvesting did not make a significant impact on ground vegetation in that, 8-13 years after stump removal, the vegetation and mosses had larger field cover [27].

Changes of vegetation, ground disturbance, and decomposition of organic material cause changes in $\mathrm{CO}_{2}$ flux. No significant differences in this measure had been found between conventional harvesting and stump removal in the first two years [28]. In addition, in the medium-term (20-30 years), the influence had not been significant in mineral soil but had been significant $(p<0.05)$ in humus [29].

There is not much information about the long-term impact of stump harvesting on carbon and nitrogen stock, as well as there is not much information about long term impact on vegetation and forest stand. Even so, short term impact of 0-20 years after stump harvesting [12,23] and medium-term impact of 20-30 years after stump harvesting [17,28,29] is rather well assessed. Almost all studies are located in areas North from latitude 58 and South from latitude 55 [15], leaving the hemiboreal forests out. The aim of this study was to characterize the long-term influence of stump harvesting on hemiboreal pine forest ecosystem, as indicated by ground vegetation.

\section{Methods and Materials}

\subsection{Study Site}

Study areas were located in Scots pine stands in western and central part of Latvia: Vacciniosa forest type with dry nutrient-poor acidic sandy soil $\left(56^{\circ} 45^{\prime} \mathrm{N}, 24^{\circ} 35^{\prime} \mathrm{E}\right)$, Myrtillosa forest type with nutrient-poor podzolic sandy soil $\left(57^{\circ} 19^{\prime} \mathrm{N}, 22^{\circ} 03^{\prime} \mathrm{E}\right)$, and Myrtillosa mel. forest type with drained peaty soils $\left(56^{\circ} 22^{\prime} \mathrm{N}, 21^{\circ} 12^{\prime} \mathrm{E}\right.$; Figure 1$)$. Climatic conditions are similar in all sites: mean monthly temperature ranging from $-1.2{ }^{\circ} \mathrm{C}$ to $-6.1{ }^{\circ} \mathrm{C}$ in January and $16^{\circ} \mathrm{C}$ to $19.4{ }^{\circ} \mathrm{C}$ in July, the mean annual precipitation is $725 \mathrm{~mm}$, and vegetation period $\sim 202$ days [30]. 

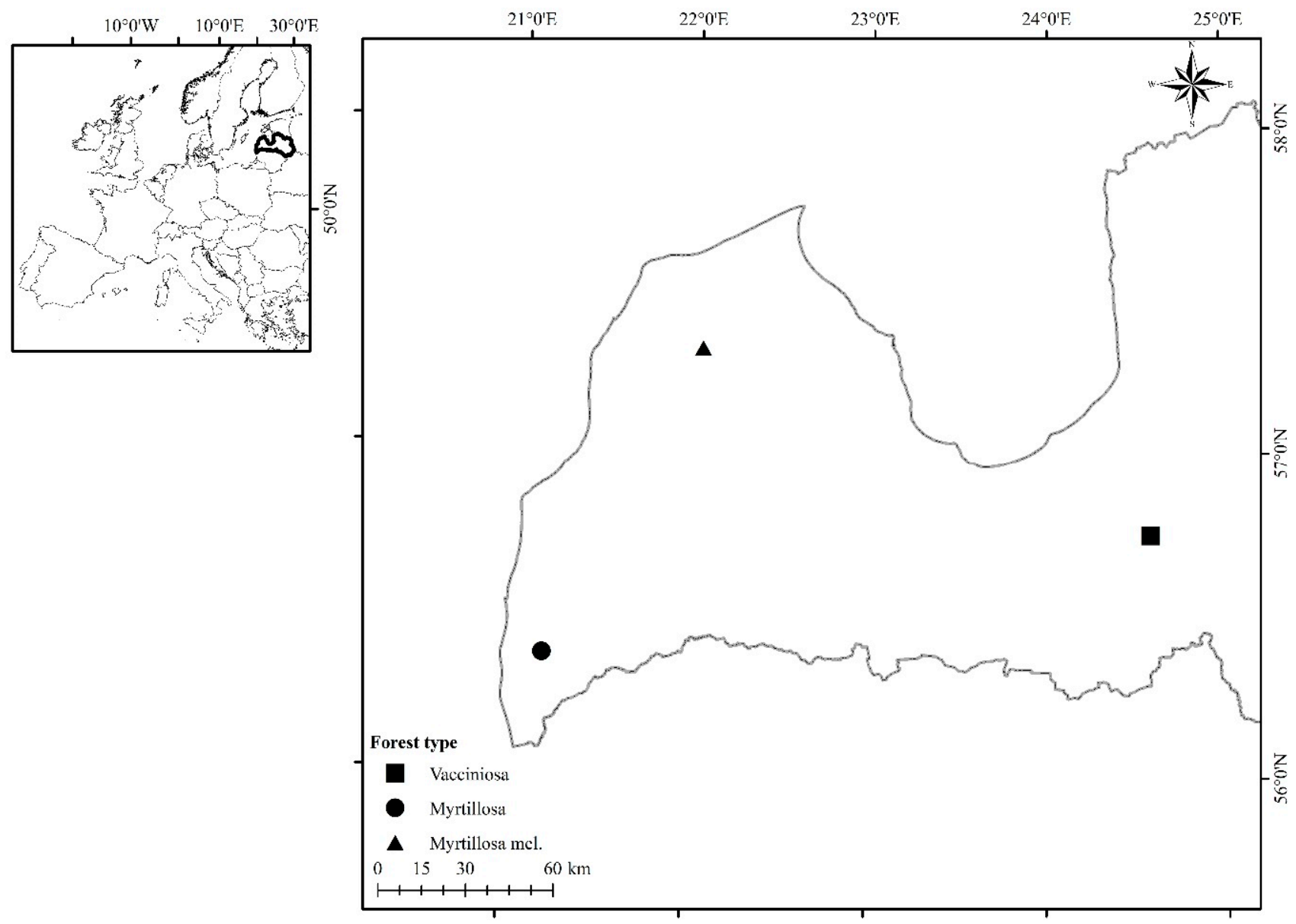

Figure 1. Location of study areas in Latvia. (Left) Location of Latvia in Europe. (Right) Stand locations in Latvia.

Study areas were selected based on documented information about specific management: in 1968, after a clear-cut, all aboveground and stump biomass, together with the upper soil layer (ca. $8 \mathrm{~cm}$ thick) was moved with a bulldozer, resulting in full biomass removal (FBR). The nearby areas in the same forest types were selected for the comparison: young stand ( $\sim 11$ years) and middle age (control) stand ( $\sim 50$ years), both established after conventional harvesting (only stem-wood removed), as well as mature stand ( 120 years) and old stand ( 160 years) (Table 1 , Table S5).

Table 1. Forest inventory data of stands with and without stump harvesting.

\begin{tabular}{|c|c|c|c|c|c|c|c|c|}
\hline Forest Type & Type & Composition Ratio & Age & Stand & $\mathrm{H}^{1}, \mathrm{~m}$ & $\mathrm{DBH}^{2}, \mathrm{~cm}$ & Basal Area, $\mathrm{m}^{2} \mathrm{ha}^{-1}$ & Yield, $\mathrm{m}^{3} \mathrm{ha}^{-1}$ \\
\hline Vacciniosa & FBR stand & $10 \mathrm{P}^{3}$ & 50 & $504-66-11$ & 19 & 22.6 & 21.7 & 198.9 \\
\hline Vacciniosa & Control stand & $10 \mathrm{P}$ & 53 & $508-110-4$ & 18.6 & 18.4 & 19.6 & 179.5 \\
\hline Vacciniosa & Control stand & $10 \mathrm{P}$ & 48 & $508-109-16$ & 17.9 & 20.23 & 14.6 & 128.3 \\
\hline Vacciniosa & Control stand & $10 \mathrm{P}$ & 51 & $504-66-17$ & 18.1 & 18.2 & 35.4 & 311.6 \\
\hline Myrtillosa & FBR stand & $10 \mathrm{P}$ & 40 & $705-246-2$ & 17.5 & 20.2 & 22.4 & 194.1 \\
\hline Myrtillosa & Control stand & $10 \mathrm{P}$ & 41 & $710-300-36$ & 19.5 & 24.2 & 25.3 & 240.0 \\
\hline Myrtillosa & Control stand & $10 \mathrm{P}$ & 35 & $713-300-14$ & 17.7 & 22.1 & 28.1 & 248.0 \\
\hline Myrtillosa & Control stand & $8 \mathrm{P} 2 \mathrm{E}^{4}$ & 40 & $713-205-19$ & 16.3 & 22 & 15.8 & 127.4 \\
\hline Myrtillosa & Control stand & $9 \mathrm{P}^{1 \mathrm{~B}^{5}}$ & 40 & $705-195-33$ & 15.3 & 15.3 & 29.8 & 229.1 \\
\hline Myrtillosa mel. & FBR stand & $10 \mathrm{P}$ & 41 & $209-418-10$ & 21.2 & 24.6 & 30.3 & 302.2 \\
\hline Myrtillosa mel. & FBR stand & $10 \mathrm{P}$ & 35 & $209-419-8$ & 17.8 & 22.9 & 24.8 & 218 \\
\hline Myrtillosa mel. & Control stand & 9P1E & 41 & $209-448-17$ & 13.9 & 18.5 & 21.8 & 159.8 \\
\hline Myrtillosa mel. & Control stand & 9P1B & 43 & $709-216-1$ & 17.6 & 19.9 & 23.5 & 200.4 \\
\hline
\end{tabular}

${ }^{1} \mathrm{H}-$ Mean tree height in the stand; ${ }^{2} \mathrm{DBH}-$ Mean tree diameter at $1.3 \mathrm{~m} ;{ }^{3} \mathrm{P}-$ Scots pine; ${ }^{4} \mathrm{E}-$ Norway spruce; ${ }^{5} \mathrm{~B}-\mathrm{Silver}$ birch. Composition ration-proportion of each tree species in the stand, based on its standing volume. 
Data were collected in July of 2015, half a century (48 years) after FBR. Vegetation was evaluated in altogether forty transects ( $50 \mathrm{~m}$ each), placed in the stands not closer than $15 \mathrm{~m}$ from the edges. On each transect, 17 sampling plots (total 680), with size $1 \mathrm{~m} \times 1 \mathrm{~m}$, were placed with regular spacing $(2 \mathrm{~m})$. In each sampling plot, ground cover vegetation and bare soil cover (including wood residuals and debris) were described by the Braun-Blanquet method [31].

Additionally, approximately in the middle of each FBR and middle age stand transect, soil samples $\left(100 \mathrm{~cm}^{3}\right)$ were collected from the depth of $0-10 \mathrm{~cm} ; 10-20 \mathrm{~cm} ; 20-40 \mathrm{~cm}$; and $40-80 \mathrm{~cm}$, and one litter sample $10 \times 10 \mathrm{~cm}^{2}$, without any living plant. The samples were transported to Latvian State Forest Research Institue "SILAVA" laboratory where they were analyzed. To measure the total amount of carbon in the soil was used elemental analysis method by [32]. To measure the total amount of N, we used Kjeldahl method by LVS ISO 11261:2002 [33,34] and, to measure the total amount of carbon in forest stand, we used elemental analysis method, accepting that conifers and deciduous trees average carbon values are $50.8 \%$ and $48.8 \%$ [35].

\subsection{Data Analysis}

The mean relative cover of every species in each stand was calculated. Species diversity for each stand was described by Shannon $\left(\mathrm{H}^{\prime}\right)$ indices $(H)=-\sum_{i=1}^{S} p_{i} \ln p_{i}$, where $\mathrm{p}$ is the proportion $(n / N)$ of individuals of one particular species found $(n)$ divided by the total number of individuals found $(\mathrm{N}), \ln$ is the natural $\log , \Sigma$ is the sum of calculations, and $s$ is the number of species [36]. The similarity of indices was statistically verified using analysis of variance at the significance level $p<0.05$ in program R 3.4.2 [37]. The Analysis of Similarities (ANOSIM) in program R, using package "vegan" [38,39] was used for the statistical comparison of the composition of vegetation between all the stands in one forest type. The $\mathrm{R}$ value (between 0 and 1$)=\frac{\left(\overline{r_{B}}-\overline{r_{W}}\right)}{\frac{1}{2} M}$, where $r_{\mathrm{B}}$ is the average rank of similarities of pairs of samples originating from different sites, $r_{\mathrm{W}}$ is the average of rank similarity of pairs among replicates within sites, $M=n(n-1) / 2$, where $n$ is the number of samples, derived from this analysis, characterizes the level of similarity: if $R=0$, then stands are same, and, if $\mathrm{R}=1$, then stands are completely different. The similarity of species composition among the stands was assessed by the Detrended Correspondence Analysis (DCA) based on the relative cover of species [40]. To characterize the growing conditions in all forest types, we used Ellenberg indicator values for vascular plants [41] and Düll indicator values for mosses [42]. Analysis of variance was used to test the similarity of the carbon and nitrogen concentration between all same age control stands and FBR stand.

\section{Results}

Most undergrowth species were found in stump harvested (FBR) Myrtillosa mel. forest type (10 species); in FBR Myrtillosa forest type was the second highest undergrowth species (8 species); but, in FBR Vacciniosa, there were only five undergrowth species. In the control stand, undergrowth species were less common in all forest types, where such undergrowth species as Betula pendula, Frangula alnus, Picea abies, and Pinus sylvestris were in all stands. Myrtillosa forest type was with ruderal specie Amelanchier spicata, and the Myrtillosa mel. forest type was with invasive species Prunus domestica, which is gone wild from nearest gardens (Table 2; Table S1). 
Table 2. Occurrence of undergrowth and advance regeneration in study areas.

\begin{tabular}{|c|c|c|c|}
\hline Species & Vacciniosa & Myrtilliosa & Myrtilliosa Mel. \\
\hline Acer platinoides & - & $x$ & $x$ \\
\hline Amelanchier spicata & - & $x$ & - \\
\hline Betula pendula & $\times$ & $x$ & $x$ \\
\hline Betula pubescens & - & - & $x$ \\
\hline Cerasus avium & - & $\times$ & - \\
\hline Corylus avellana & - & $x$ & - \\
\hline Frangula alnus & $x$ & $x$ & $\times$ \\
\hline Picea abies & $\times$ & $\times$ & $\times$ \\
\hline Pinus sylvestris & $\times$ & $\times$ & $x$ \\
\hline Populus tremula & $\times$ & $x$ & - \\
\hline Prunus domestica & - & - & $x$ \\
\hline Quercus robur & - & $x$ & - \\
\hline Salix sp. & - & - & $x$ \\
\hline Sorbus aucuparia & - & $x$ & $\times$ \\
\hline Tilia cordata & $\times$ & - & $\times$ \\
\hline Viburnum opulus & - & $x$ & - \\
\hline
\end{tabular}

Vacciniosa FBR and the control stand had the highest number of ground vegetation species (22 and 24), but the lowest number of species were found in a mature stand (14 species). The highest Shannon-Wiener index was in the young stand (1.57), and the lowest was in FBR site (1.05). The FBR stand had statically similar Shannon-Wiener indexes with the control stand and mature stand, but the young stand has no similarities with other stands (Table 3).

Table 3. Number of species and Shannon-Wiener diversity indices in the study area of Vacciniosa, Myrtillosa, Myrtillosa mel.

\begin{tabular}{|c|c|c|c|c|c|c|}
\hline Variable & Forest Type & FBR $^{5}$ & Control Stand ${ }^{1}$ & Young Stand $^{2}$ & Mature Stand $^{3}$ & Old Stand $^{4}$ \\
\hline \multirow{3}{*}{ Number of species } & Vacciniosa & 22 & 24 & 17 & 14 & 20 \\
\hline & Myrtillosa & 41 & 35 & 49 & 20 & 35 \\
\hline & Myrtillosa mel. & 78 & 46 & 20 & 51 & 43 \\
\hline \multirow{3}{*}{ Shannon- Wiener index } & Vacciniosa & $1.05^{b}$ & $1.22^{b c}$ & $1.57^{\mathrm{a}}$ & $1.09 \mathrm{bc}$ & $1.32^{\mathrm{c}}$ \\
\hline & Myrtillosa & $1.59^{\mathrm{a}}$ & $1.59^{\mathrm{a}}$ & $1.70^{\mathrm{a}}$ & $2.08^{b}$ & $1.95^{b}$ \\
\hline & Myrtillosa mel. & $1.80^{b c}$ & $1.54^{\mathrm{a}}$ & $1.63^{\mathrm{ab}}$ & $1.62^{\mathrm{ab}}$ & $1.89^{\mathrm{C}}$ \\
\hline
\end{tabular}

Different letters $\left({ }^{\mathrm{abc}}\right.$ ) show statistically significant differences. ${ }^{1}$ Control stand—conventional harvested stand at age of $\sim 50$ years; ${ }^{2}$ Young stand—conventional harvested stand at age of $\sim 11$ years; ${ }^{3}$ Mature stand-conventional harvested stand at age of $\sim 120$ years; ${ }^{4}$ Old stand — conventional harvested stand at age of $\sim 160$ years, ${ }^{5}$ FBR-stump harvested stand at age of 50 years.

Similar trends had been observed in the Myrtillosa FBR stand, which had the high number of ground vegetation species (41), but the lowest was in a mature stand (20 species); in this forest type, a young stand had highest number of species-49. The highest ShannonWiener index was in a mature and old stand (2.08 and 1.95), but the lowest was in stump harvest and the control stand (1.59 in both). The FBR stand had statistically similar ShannonWiener indexes with the control stand and young stand (Table 3). The FBR stand had the highest number of ground vegetation species also in Myrtillosa mel. (78), but the lowest was on a young stand (20 species). The highest Shannon-Wiener index was in the FBR and old stand (1.80 and 1.89), but the lowest was in the control stand (1.54). There were no statistical differences between the FBR stand and the young stand, mature stand, and old stand, but the control stand had no significant differences between the young and mature stand (Table 3). The FBR stand had as many or more species than the control stand, and it had almost the same Shannon-Wiener index.

Most common species in Vacciniosa forest type in the FBR harvested stand was moss, like Pleurozium schreberi (54.47\%), and other mosses, like Hylocomium splendens and Dicranum polysetum (Table S2). At the same age, the control stand's most common species was the same Pleurozium schreberi and Hylocomium splendens (29.83\% and $28.84 \%$ ). A high 
percentage of mosses was in Vacciniosa forest type in other control stands (mature stand and old stand) (Table S2). In the young stand, the most common species was dwarf shrubs, like Calluna vulgaris and Vaccinium vitis-idea and Dicranum polysetum (Table S2). At the FBR site, protected species Lycopodium clavatum was found, and it also was found in the same age control stand $(7.06 \%$ and $1.17 \%)$ (Table S2).

At the Myrtillosa forest type, the FBR stand most common species was Deschampsia flexuosa (38.35\%) and Pleurozium schreberi (14.61\%); at the same age, the control stand's most common species was the same, Deschampsia flexuosa $(21.25 \%)$ and Pleurozium schreberi $(16.68 \%)$. In the young stand, the most common species was Calamagrostis canescens (13.29\%), Deschampsia flexuosa (19.50\%), and Pleurozium schreberi (11.62\%); in the older control stands, the most common species was Deschampsia flexuosa (14.21\%), Hylocomium splendens $(11.03 \%)$, and Vaccinium myrtillus (10.50\%) in the mature stand, and Oxalis acetosella (18.74\%) and Hylocomium splendens (13.38\%) (Table S3).

A very similar percentage cover to species was in Myrtillosa mel. forest type FBR site; their most common species was Deschampsia flexuosa $(15.59 \%)$ and Pleurozium schreberi $(11.30 \%)$. At the control stand, the most common specie was Molinia cearulea $(14.60 \%)$; at the new stand, the most common species was Molinia cearulea $(14.29 \%)$ and Vaccinium vitis-idea $(10.06 \%)$. In the mature stand, the most common species was Deschampsia flexuosa (19.85\%), Oxyrrhynchium hians (17.58\%), and Molinia cearulea $(12.52 \%)$; in the old stand, the most common species were Pseudoscleropodium purum (15.27\%) and Calamagrostis arundinacea $(10.06 \%)$ (Table S4).

The obtained data from ANOSIM analysis in Vacciniosa forest type showed that the FBR site was most similar to the control stand $(R=0.08)$. The mature stand was also very similar to the FBR site $(\mathrm{R}=0.40)$. The old stand and young stand were more dissimilar to the FBR site. DCA analysis shows similar results, in that the FBR stand mostly overlaps with the control stand and with the mature stand. The results of DCA also follows the logical trend of vegetation development from the young to old stand (Figure 2).

In Myrtillosa forest type, the FBR site was similar to the young stand $(\mathrm{R}=0.40)$ and control stand $(R=0.44)$, and the biggest dissimilarities were between the FBR and old stand. The DCA analysis showed that the FBR stand groups together with the mature, control, and young stand. Old stand groups with mature, control, and young stand, but the old stand is the only stand that is dissimilar to the FBR site (Figure 3).

At Myrtillosa mel. forest type, the FBR site was similar to the control stand and with the mature stand $(\mathrm{R}=0.19)$, but the young stand was the most different from the FBR site $(\mathrm{R}=0.48)$. The DCA analysis showed that the FBR stand overlaps most with the control, mature, and old stand, and the DCA showed similar results to the ANOSIM analysis in all three forest types (Figure 4).

To compare growth conditions in each forest type, we used Ellenberg's indicator values. The FBR stand, in most cases (parameters and forest types), significantly differed from the control stand. In Vacciniosa forest type, in FBR stands, light conditions were similar only to the young stand, but, in the control, mature and old stand light conditions were significantly different (Table 4). The FBR stand temperature growth conditions were significantly different only from a mature stand. Moisture growth conditions in FBR site was significantly different from all control stands. And $\mathrm{pH}$ growth conditions in the FBR stand was similar to other control stands. At Myrtillosa forest type, the FBR stand light growth conditions were similar to the young stand but different than the control, mature, and old stand. The temperature, moisture, and $\mathrm{pH}$ growth conditions in the FBR stand have significant differences to all control stands. In Myrtillosa mel. forest type, the FBR stand light growth conditions had significant differences only with the old stand. The temperature growth conditions in the FBR stand had significant differences with the control stand and young stand, as Please ensure the meaning has been retained. old stand. The $\mathrm{pH}$ growth conditions in FBR stand had significant differences with control, young, and mature stand (Table 4). 


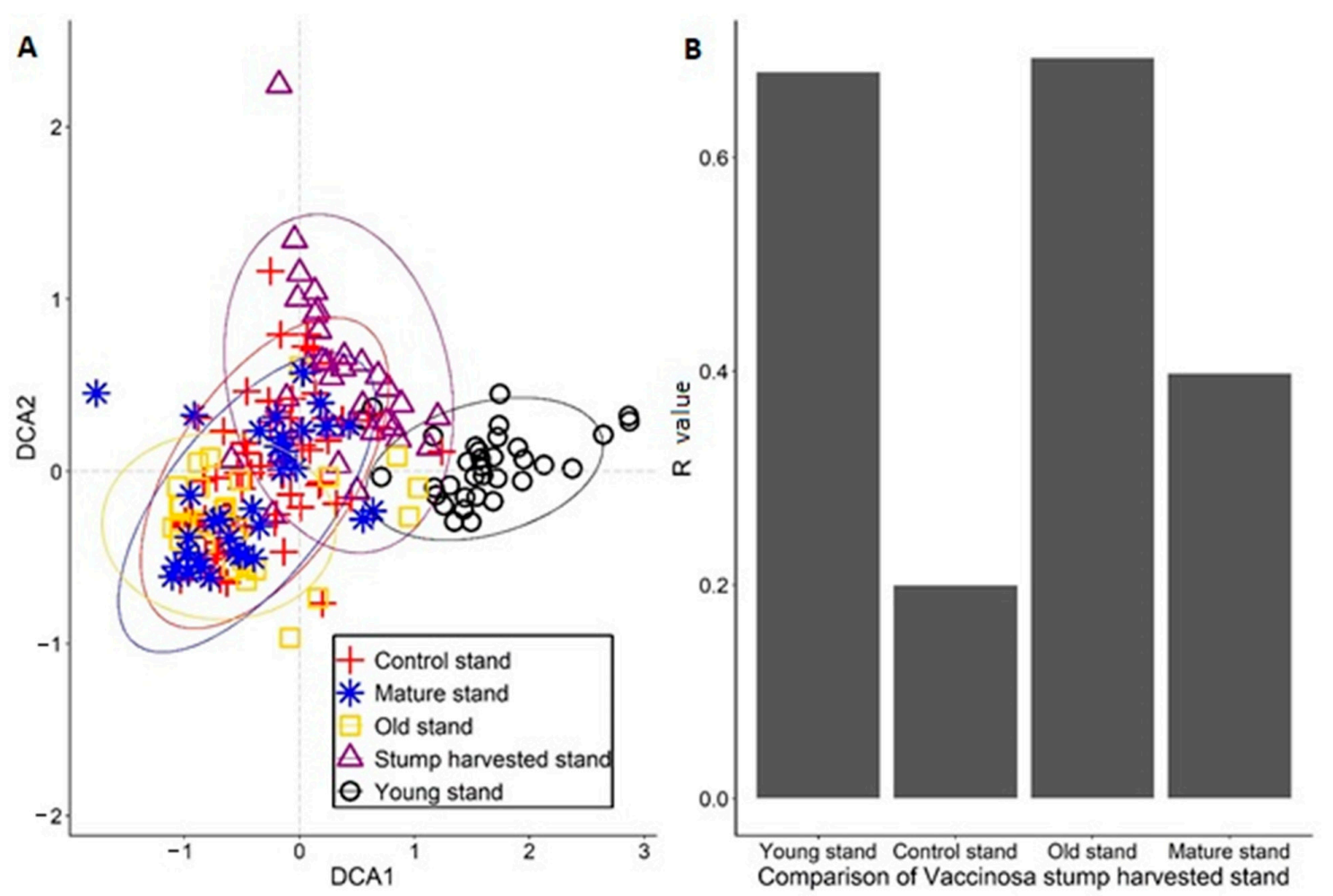

Figure 2. The detrended correspondence analysis (DCA) ordination results in a study area of Vaccinosa with ANOSIM results. (A) DCA analysis of how Vacciniosa forest type plots overlap. (B) Similar stands are compared to stump harvested stand.

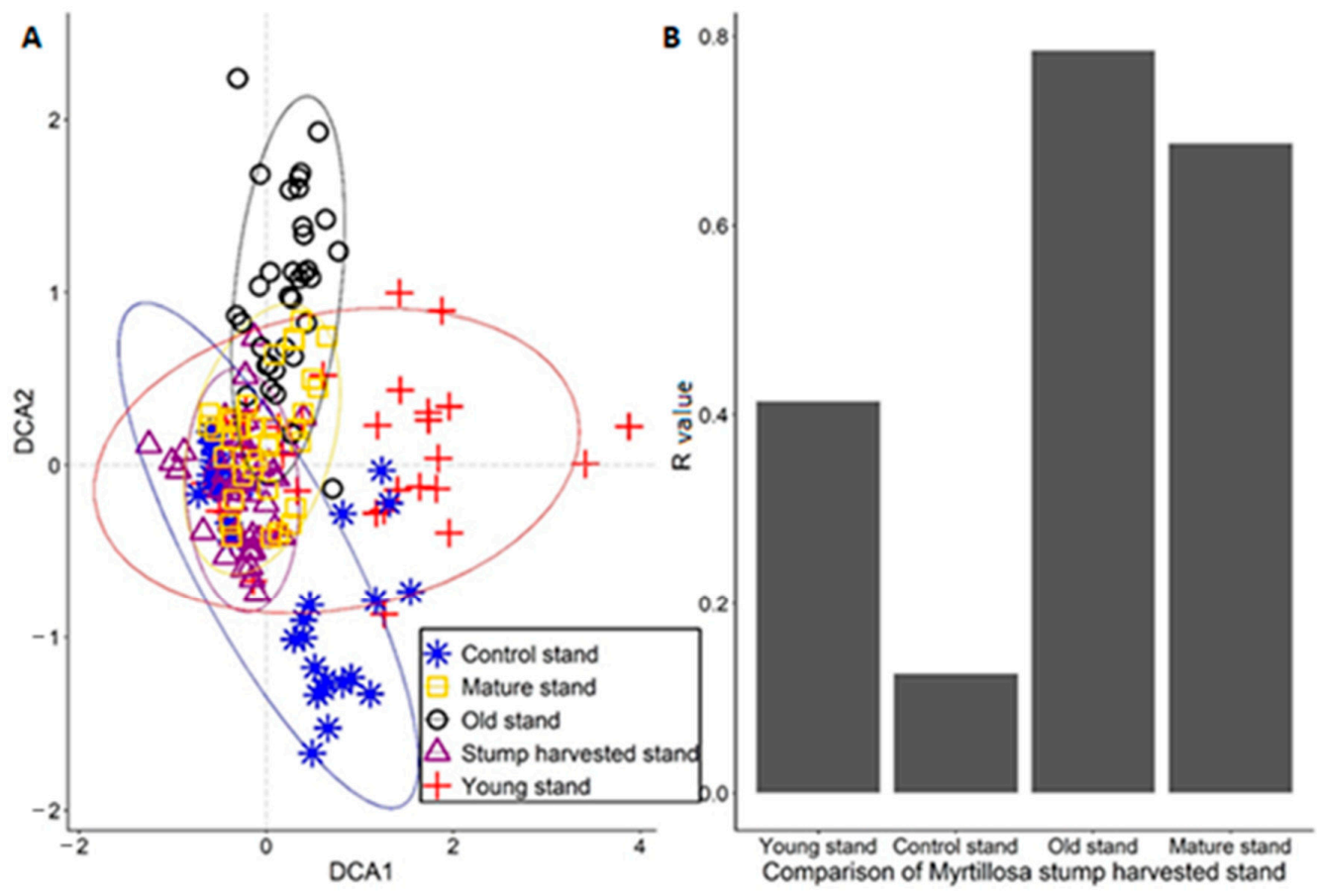

Figure 3. The DCA ordination results in a study area of Myrtillosa with ANOSIM results. (A) DCA analysis of how Myrtillosa forest type plots overlap. (B) Similar stands are compared to the stump harvested stand. 


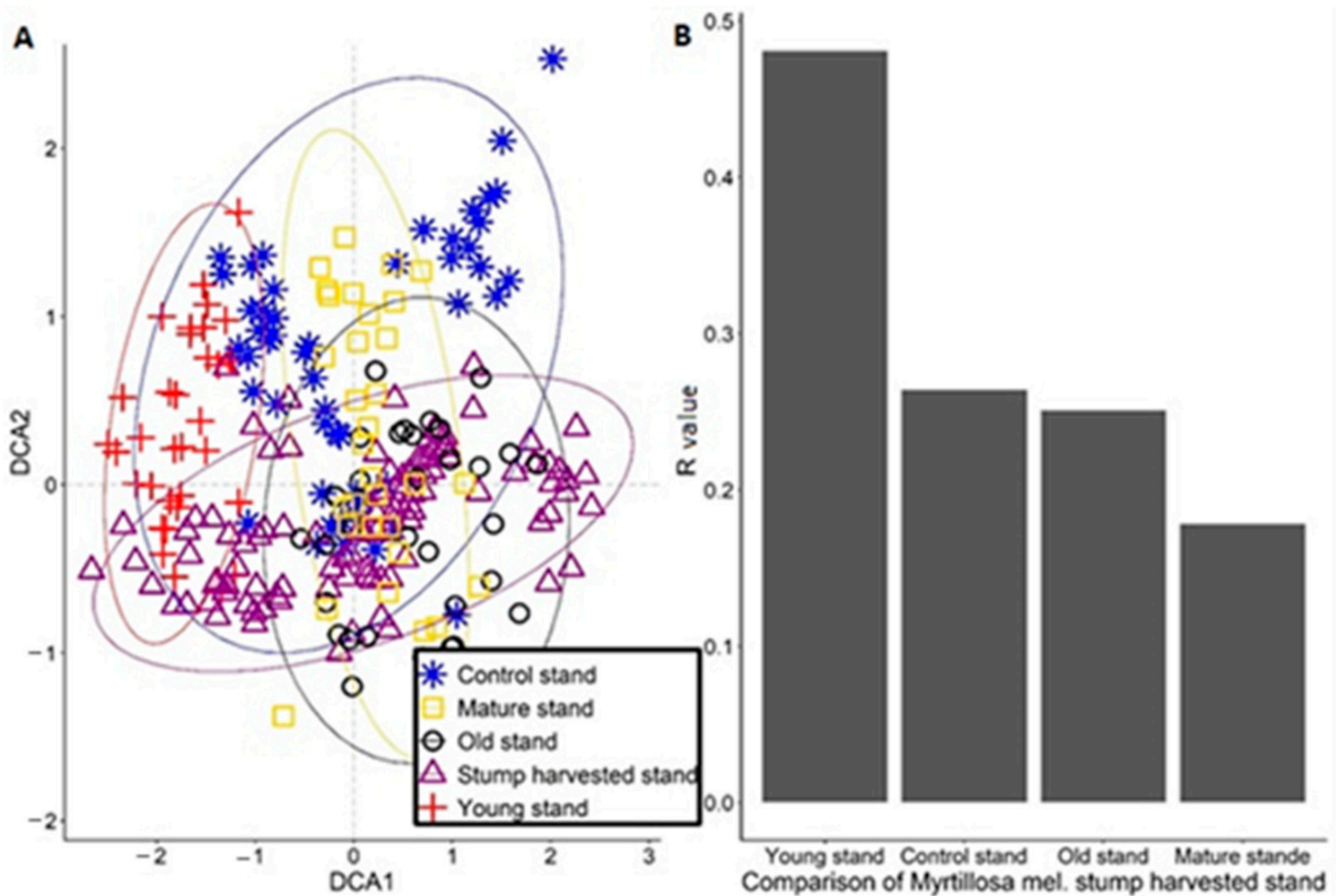

Figure 4. The DCA ordination results in a study area of Myrtillosa mel. with ANOSIM results. (A) DCA analysis of how Myrtillosa mel. forest type plots overlap. (B) Similar stands are compared to the stump harvested stand.

Table 4. The Ellenberg values for vascular plants of all forest types.

\begin{tabular}{cccccc}
\hline Forest Type & Territories & Light & Temperature & Moisture & Soil pH \\
\hline & FBR stand & $6.79^{\mathrm{a}}$ & $4.60^{\mathrm{a}}$ & $4.71^{\mathrm{b}}$ & $1.97^{\mathrm{ab}}$ \\
& Control stand & $5.66^{\mathrm{b}}$ & $4.60^{\mathrm{a}}$ & $4.97^{\mathrm{a}}$ & $2.09^{\mathrm{b}}$ \\
Vaccinosa & Young stand & $6.76^{\mathrm{a}}$ & $4.66^{\mathrm{a}}$ & $4.96^{\mathrm{a}}$ & $1.67^{\mathrm{a}}$ \\
& Mature stand & $5.31^{\mathrm{b}}$ & $4.24^{\mathrm{b}}$ & $4.97^{\mathrm{a}}$ & $1.93^{\mathrm{ab}}$ \\
& Old stand & $5.38^{\mathrm{b}}$ & $4.63^{\mathrm{a}}$ & $4.94^{\mathrm{a}}$ & $2.04^{\mathrm{ab}}$ \\
& FBR stand & $7.37^{\mathrm{b}}$ & $5.55^{\mathrm{b}}$ & $3.21^{\mathrm{b}}$ & $3.92^{\mathrm{c}}$ \\
& Control stand & $6.50^{\mathrm{a}}$ & $5.29^{\mathrm{a}}$ & $4.57^{\mathrm{a}}$ & $3.66^{\mathrm{b}}$ \\
& Young stand & $6.97^{\mathrm{ab}}$ & $5.24^{\mathrm{a}}$ & $4.58^{\mathrm{a}}$ & $4.38^{\mathrm{a}}$ \\
& Mature stand & $5.85^{\mathrm{d}}$ & $5.24^{\mathrm{a}}$ & $4.77^{\mathrm{a}}$ & $3.53^{\mathrm{b}}$ \\
& Old stand & $4.39^{\mathrm{c}}$ & $5.17^{\mathrm{a}}$ & $5.16^{\mathrm{a}}$ & $4.23^{\mathrm{a}}$ \\
& FBR stand & $6.07^{\mathrm{ab}}$ & $5.15^{\mathrm{c}}$ & $4.39^{\mathrm{c}}$ & $3.73^{\mathrm{c}}$ \\
& Control stand & $5.90^{\mathrm{a}}$ & $4.91^{\mathrm{ab}}$ & $5.38^{\mathrm{ab}}$ & $4.10^{\mathrm{b}}$ \\
& Young stand & $5.59^{\mathrm{a}}$ & $4.78^{\mathrm{a}}$ & $5.87^{\mathrm{a}}$ & $3.33^{\mathrm{a}}$ \\
& Mature stand & $6.53^{\mathrm{b}}$ & $5.08^{\mathrm{c}}$ & $4.76^{\mathrm{cd}}$ & $4.23^{\mathrm{b}}$ \\
& Old stand & $4.86^{\mathrm{c}}$ & $4.94^{\mathrm{bc}}$ & $5.04^{\mathrm{bd}}$ & $3.84^{\mathrm{bc}}$ \\
\hline
\end{tabular}

Different letters $\left({ }^{\text {abcd }}\right)$ show statistically significant differences.

To compare growth conditions for mosses, we used Düll indicator values. Unlike vascular plants, in most cases, mosses and lichens had no significant difference between the FBR and control stand. In Vacciniosa forest type, the FBR stand light and temperature conditions were significantly different only with the young stand. The moisture growth conditions in FBR stand were significantly different with the young stand and mature stand. In the FBR stand, $\mathrm{pH}$ growth conditions were significant with all control stands (Table 5). In Myrtillosa forest type, the FBR stand light growth conditions were significantly different with the mature and old stand, and moisture growth conditions in FBR stand were significantly different with mature and old stands. In Myrtillosa mel. forest type, the 
FBR stand light growth conditions was significantly different with the young stand and mature stand and had the same significant differences with temperature growth conditions. FBR stand moisture growth conditions was significantly different with control stand and mature stand and $\mathrm{pH}$ growth conditions was significantly different with all control stands (Table 5).

Table 5. The Düll values for mosses and lichens of all forest types.

\begin{tabular}{|c|c|c|c|c|c|}
\hline Forest type & Territories & Light & Temperature & Moisture & Soil pH \\
\hline \multirow{6}{*}{ Vaccinosa } & FBR stand & $5.75^{b}$ & $2.86^{b}$ & $3.95^{b}$ & $2.61^{b}$ \\
\hline & Control stand & $5.98^{b}$ & $3.00^{b}$ & $4.05^{b c}$ & $3.51^{\mathrm{a}}$ \\
\hline & Young stand & $5.22^{a}$ & $2.36^{\mathrm{a}}$ & $3.63^{a}$ & $3.33^{\mathrm{a}}$ \\
\hline & Mature stand & $5.93^{b}$ & $3.01^{b}$ & $4.21^{c}$ & $3.88^{\mathrm{ac}}$ \\
\hline & Old stand & $5.90^{b}$ & $2.86^{b}$ & $4.11^{b c}$ & $4.18^{c}$ \\
\hline & FBR stand & $6.05^{a}$ & $2.99^{a}$ & $4.33^{\mathrm{a}}$ & $3.56^{\mathrm{a}}$ \\
\hline \multirow{4}{*}{ Myrtillosa } & Control stand & $6.02^{a}$ & $3.01^{\mathrm{a}}$ & $4.34^{\mathrm{a}}$ & $3.47^{\mathrm{a}}$ \\
\hline & Young stand & $5.94^{\mathrm{a}}$ & $3.00^{\mathrm{a}}$ & $4.28^{\mathrm{a}}$ & $3.58^{a}$ \\
\hline & Mature stand & $5.47^{b}$ & $2.91^{\mathrm{a}}$ & $4.99^{b}$ & $3.37^{\mathrm{a}}$ \\
\hline & Old stand & $5.60^{b}$ & $3.04^{\mathrm{a}}$ & $4.78^{b}$ & $3.44^{\mathrm{a}}$ \\
\hline \multirow{5}{*}{ Myrtillosa mel. } & FBR stand & $3.72^{b}$ & $2.16^{\mathrm{ab}}$ & $3.00^{b}$ & $3.52^{c}$ \\
\hline & Control stand & $4.67^{b c}$ & $2.71^{b c}$ & $3.89^{a}$ & $4.57^{b}$ \\
\hline & Young stand & $2.32^{a}$ & $1.66^{\mathrm{a}}$ & $3.92^{\mathrm{ab}}$ & $1.72^{\mathrm{a}}$ \\
\hline & Mature stand & $5.58^{c}$ & $3.36^{\mathrm{c}}$ & $4.15^{\mathrm{a}}$ & $5.43^{b}$ \\
\hline & Old stand & $4.43^{b c}$ & $2.65^{b c}$ & $3.60^{a b}$ & $4.14^{b}$ \\
\hline
\end{tabular}

Different letters $\left({ }^{a b c}\right)$ show statistically significant differences.

Analyzing soil parameters as carbon and nitrogen in the soil, there were no significant differences between the FBR and control stand. In all forest types, carbon and nitrogen were more in the FBR stand.

Amount of $C$ in trees have a significant difference $(p<0.05)$ between control stands and FBR stands in Vacciniosa. In Myrtillosa, the total C in the FBR stand is lower than in the control stand, but there were no significant differences ( $p>0.05)$. In Myrtillosa mel, total C was higher in the FBR stand, but there was no significant difference between (Table 6).

Table 6. Carbon pools, soil density, and $\mathrm{pH}$ in control stands and full biomass removal (FBR) stands.

\begin{tabular}{ccccc}
\hline Forest Type & FBR Stand / Control Stand & Total C & Soil Density & pH \\
\hline Vacciniosa & FBR stand & 112.19 & 1164.62 & 5.47 \\
Vacciniosa & Control stand & 140.75 & 754.00 & 4.85 \\
Myrtillosa & FBR stand & 112.96 & 1597.53 & 4.64 \\
Myrtillosa & Control stand & 120.93 & 1445.27 & 3.82 \\
Myrtillosa mel. & FBR stand & 142.82 & 1397.00 & 4.30 \\
Myrtillosa mel. & Control stand & 113.24 & 1343.88 & 4.10 \\
\hline
\end{tabular}

\section{Discussion}

According to results, the FBR stand in Vacciniosa forest type had a significant effect on ground cover vegetation between all stands (Table 3), the Pleurozium schreberi was dominating in the FBR stand because it favors disturbances [43], and after mechanized forestation, which was mainly used in former Soviet Union to speed up the forestation process, which left large bare soil territories with only spruce seedlings planted [44]. The other reason why Pleurozium schreberi dominates in the FBR stand is that it has great anatomy (stable stem and well-placed branches) [45]. But the large dominance of Pleurozium schreberi has some negative effects on ground vegetation; it lowers the richness and the number of species in the FBR stand, but the differences were not significant (Table S2). More factors can change vegetation structure in the forest, mostly often anemochory [46] and zoochory [47]. Both large and small scale topographic conditions were flat, which most 
likely will not influence ground vegetation species. And it might be the reason why, in control and FBR stands, there are so many species.

According to results in forest type Myrtillosa, there was Deschampsia flexuosa dominance in all stands, but mostly in FBR; this shows the big influence of bare soil after stump harvesting that is because Deschampsia flexuosa have a great tolerance to exposure and disturbances [48]. But there were more dominating species in other stands, like Pleurozium schreberi and Calamagrostis canescens, and these species can spread rapidly [24,49], which is why, in the FBR stand and control stand, there were lower Shannon-Wiener indexes. In Myrtillosa forest type, dominance of one specie did not have as much impact as in Vacciniosa forest type with Pleurozium schreberi, and this is because richness was statistically even in same age control stand and in a young stand. At older stands (mature stand and old stand), there was a dominance of plants Vaccinium myrtillus, Oxalis acetosella, and Hylocomium splendens with a high tolerance of shading [50-52].

Similar dominance was with Myrtillosa mel. forest type, but, in younger and same age control stands with conventional harvesting, there was large Molinia cearulea dominance, and this is because it has a large and deep root system, which is mostly unaffected after conventional harvesting $[53,54]$. In addition, the small seeds can more easily spread across the vegetation-covered soil and even get through a dense ground cover of vegetation and litter [55]. Looking at the FBR site, it almost has two times higher number of species, and species richness is statistically different from same-age control stands because of species percentage differences (Table S4). The two most common species were Calamagrostis canescens and Pleurozium schreberi, which can aggressively spread after stump harvesting [43,49]. It was observed that, in older stands, increasing humidity and shading allowed the mosses to spread in these forests [56].

In Vacciniosa forest type, to better compare territories similarity, we used two analyses (ANOSIM and DCA), and these analyses confirmed that FBR site is most similar with same-age control stand, confirmed by other researchers [24]. Both results decline our hypothesis that, in the long term, the impact will be negative on studied forest stand. In addition, the most different stands from FBR stand were young stand and old stand because of the intense of available sunlight and soil fertility [57] (Figure 2). In Myrtillosa forest type, the (ANOSIM and DCA) analysis showed almost the same similarities as it was in Vacciniosa forest type, except that young stand was more similar than older stands (Figure 3). In Mytillosa mel. forest type, there were completely different results in (ANOSIM and DCA) analysis. The results showed that most similar stands with the FBR stand were all stands where stand age was over 40 years (Figure 4). It is because, in all these two stands, there were similar species, like Deschampsia flexuosa and mosses, like Pleurozium schreberi and Hylocomium splendens (Table S4). The young stand was most dissimilar because there was recent conventional harvesting, which changed the growing conditions [58]. These two analyses showed that stump harvesting does not have a negative impact in the long term, and there were all characteristic species, which was typical to Myrtillosa mel. forest type $[24,59]$.

The values of Ellenberg and Düll well describe the growing conditions in the forest; each forest type has its own complex of characteristic species that characterize its growing conditions [57]. Thus, if the forest is disturbed, as well as if the amount of light, temperature, humidity, and chemical composition changes, it changes the growing species in the community forest [57]. This might have further consequences to change the forest types or even the forest stand can completely degrade [60]. In Vacciniosa, there were different species which better grow in the shade, like Luzula Pilosa, and Vaccinium myrtillus that better grows in partial shade [57]. According to results, in the FBR stand, there mostly grows plant communities that required well-lit areas to grow [57], and these communities were similar to young stand plant communities (Table 4). The moisture regime in FBR stand differed significantly from other stands, but it was also likely to be affected by adjacent clear-cutting, so additional sunlight came from the side, which may have contributed to soil drying in sunny weather $[58,61,62]$. The environmental acidity of the FBR stand did 
not differ significantly from other stands, as there are herbaceous plants that like acidic soils, such as Vaccinium vitis-idea, Vaccinium myrtillus, and Calluna vulgaris. Complexes of plant species in Vacciniosa stands, corresponding to herbaceous complexes growing in very acidic to acidic soils [57] (Table 4). The Düll values mostly were similar to Ellenberg values. In the young stand, the Düll indicator values showed that alpine species or species that can withstand large temperature fluctuations are also found in the territories of Latvia, such as Cetraria islandica and others that grow there [63]. In other stands were species which adapted to temperate growth conditions in boreal forests, like Hylocomium splendens [57]. The soil acidity was significantly different between FBR and other stands because there was removed organic layer with soil and stumps.

In Myrtillosa, forest type light and temperature growth conditions were similar to Vacciniosa forest type because they are similar in forest types [64]. However, the FBR area did not differ significantly from the young stand according to Ellenberg values for light. Ellenberg's light value was most likely influenced by the frequent occurrence of Deschampsia flexuosa, as it grows well in illuminated areas [57]. Due to the fact that, in the Myrtillosa forest type, the mature stand and the old stand had thicker undergrowth, this affected the light conditions for herbaceous species and made more difficulties to adapt to [57], which is why both stands differed significantly from other stands. In terms of temperature values, the growing conditions in the FBR stand differed significantly from the other stands, and their growing conditions correspond to a moderate temperature range, as evidenced by the frequent occurrence of Deschampsia flexuosa and Calamagrostis arundinacea [57]. Ellenberg values for humidity showed that FBR stand differs significantly from other stands. The FBR stand was dominated by arid plants, such as Deschampsia flexuosa, but the remaining stands had wetter soil, as indicated by Ellenberg's mean moisture values, as well as some species that were not present in the FBR stand due to drought, such as Calamagrostis canescens. The environmental acidity in all stands was close to moderately acidic soil, as evidenced by Ellenberg averages. According to Düll values for mosses and lichens, they did not differ practically in any of the growing conditions, they showed a similar tendency with herbaceous floor stands (Table 5).

In Myrtillosa mel. the values of herbaceous Ellenberg floor for the amount of light differed significantly only between FBR and the old stand. The old stand had partial light growth conditions according to Ellenberg averages, as evidenced by the frequent occurrence of Vaccinium myrtillus, as this species likes partially shaded areas [57]. Ellenberg average values for temperature for FBR stand differed significantly from the young stand and same-age control stand, but moderate-temperature area plant communities (such as Calamagrostis arundinacea and Vaccinium myrtillus) grew in all areas [57]. All stands, except FBR, had wet growing conditions, again proving that FBR stand received more light than other stands. In addition, FBR stand had plant communities that grow best in partial shade (Pseudoscleropodium purum), which may indicate heterogeneous conditions and a wetter microclimate in some areas. FBR stands had partial acidity growth conditions according to Ellenberg values, and they did not differ significantly from the old stand, these changes in soil $\mathrm{pH}$ can be explained by the need of moss species for an acidic soil [65]. From the Düll values obtained in the moss and lichen floor, in the Myrtillosa mel. forest type, it can be concluded that the young stand grew plants that grow better in wetter environmental conditions, such as Oxyrrhynchium hians $[49,57,61]$; this is most likely explained by the fact that the young stand has preserved moss species from the previous stand, where there was probably a large undergrowth [66]. According to Düll values, the temperature in the young stand was the lowest and corresponds to the communities of alpine species [63] because Sphagnum capillifolium with a high percentage cover was found there, which was probably the reason for this low value (1.66).

This may explain why, in all forest stands, there were some commitments between yields, basal areas, and plants which were growing in those stands. This may be the reason why we did not find similarities between control stand and FBR stand, by Ellenberg and 
Düll values in light. So, we think that yield and basal area might affect all vascular plants, bryophytes, and lichens in those stands.

\section{Conclusions}

Ground vegetation of hemiboreal Scots pine forests, where stump harvesting and full biomass removal (FBR) was carried out, had fully recovered, and almost half a century after the treatment, consists of species characteristic for the particular forest types, including protected species. Similarly, no long-lasting significant influence of FBR on soil carbon nor nitrogen pools had been found. It demonstrates the ability of hemiboreal forest ecosystem to recover after severe disturbances and the potential for more intensive forest management without adverse impact to this ecosystem. Caution must be applied while implementing this approach over a large area, since spatial (forest landscape) effects, not assessed in this study, may have played a role to ensure efficient recovery of ground vegetation. Continuous monitoring of stands after the FBR would provide better understanding on the patterns and causal links of ground vegetation recovery and shifts in soil chemical composition, therefore needing to be addressed in future.

Supplementary Materials: The following are available online at https://www.mdpi.com/2071-105 0/13/4/2095/s1, Table S1: Occurrence of underwood and advance growth of control sites, Table S2: The percentage cover of most common species in the Vacciniosa study area, Table S3: The percentage cover of most common species in the Myrtillosa study area, Table S4: The percentage cover of most common species in the pine Myrtillosa mel study area.

Author Contributions: Conceptualization, Ā.J. and I.D.; methodology, I.D. and A.B.; formal analysis, D.E., R.Č. and I.D.; data curation, I.D. and L.Č.; writing—original draft preparation, R.Č. and I.D.; writing—review and editing, Â.J. and Z.L.; supervision, Â.J.; project administration, Z.L. All authors have read and agreed to the published version of the manuscript.

Funding: This research was funded by LVM project "Impact of forest management on forest and related ecosystem services".

Institutional Review Board Statement: Not applicable.

Informed Consent Statement: Not applicable.

Data Availability Statement: Data available on request due to policy of the Institute.

Conflicts of Interest: The authors declare no conflict of interest.

\section{References}

1. Šreinerts, P. Kurzemes hercogistes mežsaimniecība un meža likumi 16. un 17. gadu simtenī. Lat. Uni. Rak Lauksai. Fakul. Ser. 1939, 4,381-411.

2. Kaye, T.P. Pine Tar; History and Uses; San Francisco Maritime Park Association: San Francisco, CA, USA, 1997; Available online: http:/ / www.maritime.org/conf/conf-kaye-tar.htm (accessed on 5 February 2021).

3. Morozovs, A.; Irbe, I.; Bukšāns, E. Koksnes Kīmiskā Pārstrāde un Aizsardzība.; Avots: Riga, Latvia, 2018; 172p.

4. Helmisaari, H.S.; Makkonen, K.; Kellomäki, S.; Valtonen, E.; Mälkönen, E. Below- and above-ground biomass, production and nitrogen use in Scots pine stands in eastern Finland. For. Ecol. Manag. 2002, 165, 317-326. [CrossRef]

5. Iivonen, S.; Kaakinen, S.; Jolkkonen, A.; Vapaavuori, E.; Linder, S. Influence of long-term nutrient optimization on biomass, carbon, and nitrogen acquisition and allocation in Norway spruce. Can. J. For. Res. 2006, 36, 1563-1571. [CrossRef]

6. Liepiňš, J. Kokaudžu biomasas noteikšanas metodikas izstrāde un oglekla uzkrājuma aprēkini Latvijā. Ph.D. Thesis, Latvia University of Life Sciences and Technologies, Jelgava, Latvia, 27 August 2019.

7. Urban, J.; Čermák, J.; Ceulemans, R. Above- and below-ground biomass, surface and volume, and stored water in a mature Scots pine stand. Eur. J. For. Res. 2015, 134, 61-74. [CrossRef]

8. Cienciala, E.; Černý, M.; Tatarinov, F.; Apltauer, J.; Exnerová, Z. Biomass functions applicable to Scots pine. Trees Struct. Funct. 2006, 20, 483-495. [CrossRef]

9. LUKE. Natural Resources Institute Finland—Statistics Database. Available online: https://stat.luke.fi/en/energy-2016_en-0 (accessed on 1 September 2020).

10. Carey, M.L. Whole Tree Harvesting in Sitka Spruce. Possibilities and Implications. Ir. For. 1980, 37, 48-63.

11. Nisbet, T.; Dutch, J.; Moffat, A. Harvesting a Guide to Whole -Tree Harvesting; Forestry Practice: Edinburgh, UK, 1997; pp. 1-11. 
12. Kataja-aho, S.; Fritze, H.; Haimi, J. Short-term responses of soil decomposer and plant communities to stump harvesting in boreal forests. For. Ecol. Manag. 2011, 262, 379-388. [CrossRef]

13. Mitchell, D. Stump Harvesting. In Proceedings of the 2009 COFE: Environmentally Sound Forest Operations 32nd Annual Meeting of the Council on Forest Engineering, North Tahoe Conference Center, Kings Beach, CA, USA, 15-18 June 2009 ; p. 6.

14. Heninger, R.; Scott, W.; Dobkowski, A.; Miller, R.; Anderson, H.; Duke, S. Soil disturbance and 10-year growth response of coast Douglas-fir on nontilled and tilled skid trails in the Oregon Cascades. Can. J. For. Res. 2002, 32, 233-246. [CrossRef]

15. Thiffault, E.; Béchard, A.; Paré, D.; Allen, D. Recovery rate of harvest residues for bioenergy in boreal and temperate forests: A review. Wiley Interdiscip. Rev. Energy Environ. 2015, 4, 429-451. [CrossRef]

16. Vanguelova, E.I.; Pitman, R.; Benham, S.; Perks, M.; Morison, J.I. Impact of tree stump harvesting on soil carbon and nutrients and second rotation tree growth in Mid-Wales, UK. Open J. For. 2017, 7, 58-77. [CrossRef]

17. Karlsson, K.; Tamminen, P. Long-term effects of stump harvesting on soil properties and tree growth in Scots pine and Norway spruce stands. Scand. J. For. Res. 2013, 28, 550-558. [CrossRef]

18. Palviainen, M.; Finér, L.; Laiho, R.; Shorohova, E.; Kapitsa, E.; Vanha-Majamaa, I. Carbon and nitrogen release from decomposing Scots pine, Norway spruce and silver birch stumps. For. Ecol. Manag. 2010, 259, 390-398. [CrossRef]

19. Palviainen, M.; Finér, L.; Kurka, A.M.; Mannerkoski, H.; Piirainen, S.; Starr, M. Decomposition and nutrient release from logging residues after clear-cutting of mixed boreal forest. Plant Soil 2004, 263, 53-67. [CrossRef]

20. Novák, J.; Dušek, D.; Kacálek, D.; Slodičák, M. Analysis of biomass in young Scots pine stands as a basis for sustainable forest management in Czech lowlands. J. For. Sci. 2017, 63, 555-561. [CrossRef]

21. Bílek, L.; Remeš, J.; Fulín, M.; Chalupová, T.; Procházka, J. Množství a distribuce nadzemní biomasy borovice lesní v oblasti přirozených borů. The amount and distribution of above-ground biomass of Scots pine on natural pine sites. Zpráry Lesn. Výzk. 2016, 61, 108-114.

22. Saarsalmi, A.; Tamminen, P.; Kukkola, M.; Hautajärvi, R. Whole-tree harvesting at clear-felling: Impact on soil chemistry, needle nutrient concentrations and growth of Scots pine. Scand. J. For. Res. 2010, 25, 148-156. [CrossRef]

23. Kataja-Aho, S.; Saari, E.; Fritze, H.; Haimi, J. Effects of stump removal on soil decomposer communities in undisturbed patches of the forest floor. Scand. J. For. Res. 2011, 26, 221-231. [CrossRef]

24. Olsson, B.A.; Staaf, H. Influence of Harvesting Intensity of Logging Residues on Ground Vegetation in Coniferous Forests. J. Appl. Ecol. 1995, 32, 640-654. [CrossRef]

25. Berg, S. Technology and systems for stump harvesting with low ground disturbance. Ph.D. Thesis, Swedish University of Agricultural Sciences, Umea, Sweden, 2 December 2014.

26. Pykälä, J. Immediate increase in plant species richness after clear-cutting of boreal herb-rich forests. Appl. Veg. Sci. 2004, 7, 29-34. [CrossRef]

27. Hyvönen, R.; Kaarakka, L.; Leppälammi-Kujansuu, J.; Olsson, B.A.; Palviainen, M.; Vegerfors-Persson, B.; Helmisaari, H.S. Effects of stump harvesting on soil $\mathrm{C}$ and $\mathrm{N}$ stocks and vegetation 8-13 years after clear-cutting. For. Eco. Manag. 2016, 371, 23-32. [CrossRef]

28. Strömgren, M.; Mjöfors, K.; Olsson, B.A. Soil-surface $\mathrm{CO}_{2}$ flux during the first 2 years after stump harvesting and site preparation in 14 Swedish forests. Scand. J. For. Res. 2016, 32, 213-221. [CrossRef]

29. Persson, T.; Lenoir, L.; Vegerfors, B. Long-term effects of stump harvesting and site preparation on pools and fluxes of soil carbon and nitrogen in central Sweden. Scand. J. For. Res. 2016, 32, 222-229. [CrossRef]

30. Nikodemums, O.; Klaviṇš, M.; Krišjāne, Z.; Zelčs, V. Latvija. Zeme, Daba, Tauta; Latvijas Universitātes Akadēmiskais Apgāds: Riga, Latvia, 2018; pp. 225-271.

31. Braun-Blanquet, J. Pflanzensoziologie, Grundzüge der Vegetationskunde, 3rd ed.; Springer: Wien, Austria; New York, NY, USA, 1964; p. 865.

32. LVS-Latvian Standard-ISO. Augsnes Kvalitāte. Organiskā un Kopējā Oglekla Noteikšana Pēc Sausās Sadedzināšanas (Elementanalīze); LVS ISO 10694:2006; VSIA Latvijas Standarts: Riga, Latvia, 2006; p. 12.

33. Bradstreet, R.B. Kjeldahl method for organic nitrogen. Anal. Chem. 1954, 26, 185-187. [CrossRef]

34. LVS-Latvian Standard-ISO. Augsnes Kvalitāte: Kopējā Slāpekla Noteikšana. Modificēta Kjeldāla Metode; LVS ISO 11261:2002 L; VSIA Latvijas Standarts: Riga, Latvia, 2002; p. 8.

35. Thomas, S.C.; Martin, A.R. Carbon content of tree tissues: A synthesis. Forests 2012, 3, 332-352. [CrossRef]

36. Spellerberg, I.F.; Fedor, P.J. A tribute to Claude-Shannon (1916-2001) and a plea for more rigorous use of species richness, species diversity and the 'Shannon-Wiener' Index. Glob. Ecol. Biogeol. 2003, 12, 177-179. [CrossRef]

37. R Core Team. R: A Language and Environment for Statistical Computing. R Foundation for Statistical Computing. Available online: https:/ / www.R-project.org/ (accessed on 20 May 2019).

38. Clarck, K.R. Non-parametric multivariate analyses of changes in community structure. Aust. J. Ecol. 1993, 18, 117-143. [CrossRef]

39. Oksanen, J.; Blanchet, F.G.; Kindt, R.; Legendre, P.; Minchin, P.R.; O’Hara, R.B.; Simpson, G.L.; Solymos, P.; Henry, M.H.; Wagner, H.; et al. Vegan: Community Ecology Package. R Package Version 2.0-10. 2013. Available online: http://CRAN.Rproject.org $/$ package=vegan (accessed on 5 February 2021).

40. Correa-Metrio, A.; Dechnik, Y.; Lozano-García, S.; Caballero, M. Detrended correspondence analysis: A useful tool to quantify ecological changes from fossil data sets. Bol. Soc. Geol. Mex. 2014, 66, 135-143. [CrossRef]

41. Ellenberg, H. Zeigerwerte der Gefässpflanzen Mitteleuropas; Scripta Geobotanica: Göttingen, Germany, 1974; 197p. 
42. Ellenberg, H.; Weber, H.E.; Düll, R.; Wirth, V.; Werner, W.; Paulissen, D. Zeigerwerte von Pflanzen in Mitteleuropa, 2nd ed.; Scripta Geobotanica: Göttingen, Germany, 1992; pp. 1-248.

43. Frego, K.A. Regeneration of four boreal bryophytes: Colonization of experimental gaps by naturally occurring propagules. Can. J. Bot. 1996, 74, 1937-1942. [CrossRef]

44. Salinš, Z. Meža Izmantošana Latvijā; Jelgavas Tipogrāfija: Jelgava, Latvia, 1999; pp. 46-190.

45. Schofield, W.B. Introduction to Bryology; The Blackburn Press: Caldwell, NJ, USA, 2001; 432p.

46. Auld, B.A.; Coote, B.G. A Model of a Spreading Plant Population. Oikos 1980, 34, 287. [CrossRef]

47. Schupp, E.W. Quantity, quality and the effectiveness of seed dispersal by animals. In Frugivory and seed dispersal: Ecological and evolutionary aspects. Vegetatio 1993, 107, 15-29.

48. Watson, A.; Welch, D.; Heslop, R.E.F. Deschampsia flexuosa snowbed grassland on granitic mountains in the cairngorms. Plant Ecol. Divers 2010, 3, 95-99. [CrossRef]

49. Porley, R.; Hodgetts, N. Mosses and Liverworts; HarperCollins: London, UK, 2005; 495p.

50. Christy, M. The hornbeam (Carpinus betulus L.). Br. J. Ecol. 1924, 12, 39-94. [CrossRef]

51. Ritchie, J.C. Vaccinium myrtillus L. J. Ecol. 1956, 44, 291-299. [CrossRef]

52. Jägerbrand, A.K.; During, H.J. Effects of simulated shade on growth, number of branches and biomass in Hylocomium splendens and Racomitrium lanuginosum. Lindbergia 2005, 117-124. [CrossRef]

53. Taylor, K.; Rowland, A.P.; Jones, H.E. Molinia caerulea (L.) Moench. J. Ecol. 2001, 89, 126-144. [CrossRef]

54. Hotanen, J.P.; Saarinen, M.; Nousiainen, H. Purple Moor Grass (Molinia caerulea) on peatlands drained for forestry in Finland. Suo 2016, 67, 81-90.

55. Jefferies, T.A. Ecology of the Purple Heath Grass (Molinia Caerulea). J. Ecol. 1915, 3, 93-109. [CrossRef]

56. Ross-Davis, A.L.; Frego, K.A. Comparison of plantations and naturally regenerated clearcuts in the Acadian Forest: Forest floor bryophyte community and habitat features. Can. J. Bot. 2002, 80, 21-33. [CrossRef]

57. Ellenberg, H. Vegetation Ecology of Central Europe, 4th ed.; Cambridge University Press: Cambridge, UK, 1988; 731p.

58. Priedītis, N. Latvijas Mežs: Daba un Daudzveidība; WWF-Pasaules Dabas Fonds: Riga, Latvia, 1999; 93p.

59. Berkis, A.; Meijere, A.; Sedlenieks, A.; Vanags, A.; Ansons, G.; Rove, I.; Brauns, J.; Grīslis, J.; Gaigals, J. Rokasgrāmata Meža Tipu Noteikšanai; LVM-Latvijas Valsts Meži: Riga, Latvia, 2013; 69p.

60. Ikauniece, S. Aizsargājamo Biotopu Saglabāšanas Vadlīnijas Latvijā. 6. Sējums. Meži; Dabas Aizsardzības Pārvalde: Sigulda, Latvia, 2017; 167p.

61. Pearson, G.A. Light and Moisture in Forestry. Ecology 1930, 11, 145-160. [CrossRef]

62. North, M.; Oakley, B.; Fiegener, R.; Gray, A.; Barbour, M. Influence of light and soil moisture on Sierran mixed-conifer understory communities. Plant Ecol. 2005, 177, 13-24. [CrossRef]

63. Strazdina, L.; Strazdina, L. Alpine flora of South Norway. Experience of Latvian bryologists and botanists. Lat. Veǵ. 2015, 24, 87-92.

64. Zālītis, P.; Jansons, J. Latvijas Meža Tipoloǵija un Tās Sākotne; LVMI „Silava”: Salaspils, Latvia, 2013; pp. 71-91.

65. Strazdina, L.; Madžule, L.; Brumelis, G. A contribution to the bryoflora of Moricsala island nature reserve, Latvia. Folia Cryptogam. Est. 2011, 48, 107-117.

66. Horn, H.S. Markovian Properties of Forest Succession. In The Ecology and Evolution of Communities; Harvard University Press: Cambridge, MA, USA, 1975. 